\title{
Comparative Study of Substrate-Based and Commercial Formulations of Arbuscular Mycorrhizal Fungi in Romaine Lettuce Subjected to Salt Stress
}

\section{Idoia Garmendia and Víctor Javier Mangas}

Department of Environment and Earth Sciences, University of Alicante, P.O. Box 99, E- 03080

Alicante, Spain. Tel. 34965903400 ext. 2419; Fax: 34 965909862;

Address correspondence to I. Garmendia; E-mail: idoia.garmendia@ua.es

\begin{abstract}
To compare the effect of substrate-based and commercial arbuscular mycorrhizal fungi (AMF) in salt stress tolerance of Romaine lettuce a bifactorial analysis was carried out. Under non-saline conditions, only plants inoculated with formulation 1 stimulated shoot weight but not related with greater root AMF colonization. Phosphorus and potassium concentrations in leaves were improved by mycorrhizal association. Irrigation with $100 \mathrm{mM}$ sodium chloride $(\mathrm{NaCl})$ did not affect leaf relative water content and we observed no osmotic adjustment in leaves from nonmycorrhizal plants. However, root dry biomass and its starch content decreased, while leaf starch and root soluble sugar concentrations were enhanced. Lettuce inoculated with formulation 2 and substrate-based Glomus intraradices showed the highest root colonization percentages. Nevertheless, none of the mycorrhizal treatments induced a significant improvement on growth
\end{abstract}


of lettuce subjected to salt stress. Romaine lettuce seems to be a moderately tolerant variety to salinity and therefore, the contribution of AMF was minimized.

Keywords: Glomus, Lactuca sativa, salinity, horticulture, commercial mycorrhiza

\section{INTRODUCTION}

Lettuce is considered relatively sensitive to salinity showing a reduction of growth and yield quality (Kohler et al., 2009; Martínez et al., 1996), although it depends on the variety. Romaine lettuce, one of the most commonly used salad vegetable, seems to be one of the less sensitive varieties (Nasri et al., 2011). However, dry weight, height and color of Romaine lettuce is significantly changed by long-term irrigation with moderately high sodium chloride $(\mathrm{NaCl})$ concentration (Kim et al., 2008). Salinization of agricultural soils and irrigation water is one of the major environmental problems for crop yield. Under saline conditions plants suffer osmotic stress, by limiting root water absorption, and ionic stress, resulting from high concentration of toxic ions within plant cells.

Arbuscular mycorrhizal fungi (AMF) can contribute to the salinity resistance of host plants by improving nutritional status, particularly of phosphorus $(\mathrm{P})$ and nitrogen $(\mathrm{N})$ (Jeffries et al., 2003; Ojala et al., 1983), enhancing osmotic adjustment (Augé, 2001; Azcón et al., 1996), increasing water use efficiency and uptake (Augé, 2001; Ruiz-Lozano and Azcón, 1995), stimulating photosynthetic activity (Augé and Stodola, 1990) and reducing oxidative damage (Augé, 2001). Other biological strategies to facilitate plant growth under salinity stress are the 
use of plant growth-promoting bacteria (PGPR) as Pseudomonas mendocina (Kohler et al., 2009) or Azospirillum brasilense (Barassi et al., 2006). These bioprotectors can play a significant role in soilless greenhouse lettuce culture with limited good quality water resources. For example, Azospirillum-inoculated lettuce seeds had better germination and vegetative growth than noninoculated controls after being exposed to $\mathrm{NaCl}$ (Barassi et al., 2006), and mycorrhizal symbiosis enhanced plant growth and leaf relative water content (Jahromi et al., 2008) and significantly reduced sodium $(\mathrm{Na})$ and chloride $(\mathrm{Cl})$ uptake of lettuce subjected to salt stress (Zuccarini, 2007).

Taken into account such considerations and the well known fact that the use of biological tools are useful for purposes of more sustainable horticulture, our objective was to compare the effect of substrate-based and commercial AMF inocula ameliorating the negative effect of saline conditions in soilless greenhouse Romaine lettuce.

\section{MATERIAL AND METHODS}

\section{Biological Material, Growth Conditions, and Experimental Design}

Seeds of Romaine lettuce (Lactuca sativa L. var. longifolia cv. 'Parris Island') were germinated on washed sand. When one month old, 125 seedlings were transplanted to $3 \mathrm{~L}$ plastic containers filled with a mixture of perlite-coconut fiber-sand $(1.5: 1.5: 1 \mathrm{v} / \mathrm{v} / \mathrm{v})$. When transplanted, plants were divided into five groups (25 plants per treatment): (a) non-mycorrhizal plants (NM), plants inoculated with a commercial product containing granular sand and clay with spores of a mixture 
of Glomus intraradices (Schenck and Smith) and Glomus mosseae (Nicol. and Gerd.) Gerd. and Trappe [commercial inoculum $\left.1\left(\mathrm{CI}_{1}\right)\right]$, (c) plants inoculated with a commercial product containing G. intraradices on granular expanded clay [commercial inoculum $2\left(\mathrm{CI}_{2}\right)$ ], (d) plants inoculated with bulk inoculum of Glomus intraradices (Gi), and (e) plants inoculated with bulk inoculum of Glomus mosseae $(\mathrm{Gm})$. Table 1 lists the abundance of propagules in different inocula and the rates of application into the potting substrate. Commercial formulations were used at $5 \mathrm{x}$ the recommended dose because previous studies with commercial inocula had indicated that the rate recommended by the manufacturers sometimes is too low for mycorrhizas to form within a reasonable time (Tarbell and Koske, 2007). Bulk inocula were supplied by Plant Biology Department of Navarra University (Navarra, Spain). These inocula were substrate-based and include root fragments, spores and hyphae from 3 months culture of leek and alfalfa grown in a mixture of perlite-coconut fiber $(1: 1 \mathrm{v} / \mathrm{v})$. Infectivity of bulk inocula was evaluated by Most Probable Number (MPN) assay (Schenck, 1982) with Sorghum bicolor as the host plant. The bioassay was performed with five replicates in $200 \mathrm{~mL}$ pots (perlite-coconut fiber, $1: 1 \mathrm{v} / \mathrm{v}$ ) in a greenhouse $\left(25 / 20^{\circ} \mathrm{C}\right.$ day/night and natural daylight), watered with deionized water and grown for 4 weeks. All inoculants were added to the planting hole and mixed with the surrounding potting substrate ensuring that good contact was achieved with runner roots.

Plants were drip irrigated weekly with $100 \mathrm{~mL}$ Long Ashton Nutrient Solution (LANS) (Hewitt, 1966) at one-quarter phosphorus strength to contribute to the establishment of mycorrhizal symbiosis (Azcón-Aguilar and Barea, 1997). In addition, plants received water to prevent wilting. The experiment was carried out in a greenhouse at $25 / 15^{\circ} \mathrm{C}$ day/night and plants 
received natural daylight supplemented with irradiation from sodium lamps Son-T Plus (Philips Nederland B.V., Eindhoven) during a photoperiod of $16 \mathrm{~h}$.

Salt stress was induced by $\mathrm{NaCl}(100 \mathrm{mM}$ in irrigation water) 2 months after transplanting. To avoid an osmotic shock, the concentration of $\mathrm{NaCl}$ was increased gradually during the first week to reach the desired $\mathrm{NaCl}$ concentration and maintained for additional 3 weeks. At the end of the experiment, the electrical conductivity of the substrate from non-saline

pots and the pots cultivated under salinity was about 0.45 and $2.44 \mathrm{mS} \mathrm{cm}^{-1}$, respectively. Two plant harvests were performed: the day before imposing the salt stress (two months after AMF inoculation) and after 4 weeks of saline conditions.

\section{Plant Growth parameters, Water Status and Estimation of AMF Colonization}

In each harvest, total dry matter (DM) of the different plant organs was determined after drying at $80^{\circ} \mathrm{C}$ for 2 days. Relative water content (RWC) was estimated by a modification of Weatherley's method (1950) on youngest fully mature leaves.

Root samples were cleared and stained (Phillips and Hayman, 1970) and the percentage of AMF root colonization was assessed by examining a minimum of $1001 \mathrm{~cm}$ root segments for each treatment (Hayman et al., 1976).

\section{Mineral Analyses}


Samples (0.25 g dry weight) were dry-ashed and dissolved in $\mathrm{HCl}$ according to Duque (1971). Phosphorus, potassium, magnesium, calcium, manganese, zinc, iron and sodium were determined using a Perkin Elmer Optima 4300 inductively coupled plasma optical emission spectroscopy (ICP-OES) (Perkin Elmer, Waltham, MA, USA). Total nitrogen was quantified after combustion $\left(950^{\circ} \mathrm{C}\right)$ of leaf dry matter with pure oxygen by an elemental analyzer provided with a thermal conductivity detector (TruSpec CN, Leco, St. Joseph, MI, USA). Youngest fullmature leaves were used for mineral analysis.

\section{Biochemical Analysis}

These analyses were performed on the youngest full-mature leaves harvested at midday, frozen in liquid nitrogen and stored at $-20^{\circ} \mathrm{C}$ in each harvest for later quantifications. Photosynthetic pigment content of leaves was determined according to Séstak et al. (1971). Samples (20 mg of fresh leaves) were immersed in $5 \mathrm{ml}$ of $96 \%$ ethanol at $80^{\circ} \mathrm{C}$ for 10 min to extract the pigments. The absorbance of extracts was spectrophotometrically measured and the equations reported by Lichtenthaler (1987) were used to calculate pigment concentrations.

Total soluble sugars (TSS), starch and proline in roots and leaves were quantified in potassium phosphate buffer $(\mathrm{KPB})(50 \mathrm{mM}, \mathrm{pH}=7.5)$ extracts of fresh tissue $(0.1 \mathrm{~g})$. These extracts were filtered through four layers of cheesecloth and centrifuged at $28710 \mathrm{~g}$ for $15 \mathrm{~min}$ at $4^{\circ} \mathrm{C}$. The pellet was used for starch determinations (Jarvis and Walker, 1993). The supernatant was collected and stored at $4^{\circ} \mathrm{C}$ for TSS and proline determinations. Total soluble sugars were analyzed spectrophotometrically with the anthrone reagent (Yemm and Willis, 1954). Free 
proline was estimated by spectrophotometric analysis at $515 \mathrm{~nm}$ of the ninhydrine reaction (Irigoyen et al., 1992).

\section{Statistics}

Plant DM, leaf RWC, mycorrhizal colonization, and mineral concentration in leaves the day when salt stress was imposed were analyzed with one-way analysis of variance (ANOVA). Data on parameters measured after salinity treatments were subjected to a two-factor ANOVA. The variance was related to the main treatments (AMF and salt stress) and to the interaction between them. Means \pm standard deviation $(\mathrm{SD})$ were calculated and, when the $F$-ratio was significant, least significance differences were evaluated by the Tukey-b test. When only two treatments were compared, means \pm SD were calculated and their differences tested for significance by using Student's $t$-test. Significance levels were always set at $5 \%$.

\section{RESULTS}

There were significant differences in growth parameters between lettuce plants two months after been inoculated with different mycorrhizal fungi (Table 2). Plants inoculated with commercial formulation 1 had the greatest shoot biomass and reduced its root dry matter, while the rest of AMF inocula only brought down the root biomass comparing with NM plants. Mycorrhizal colonization achieved the $42 \%$ in Gi lettuce and around $1 \%$ in the rest of mycorrhizal treatments. Non-mycorrhizal plants remained uncolonized. 
Referring to photosynthetic pigments, chlorophyll leaf concentrations were higher in $\mathrm{Gi}$, $\mathrm{Gm}$ and $\mathrm{CI}_{2}$ plants, and foliar carotenoids were accumulated specifically in lettuce inoculated with both bulk inocula (Table 2). Lettuce plants showed good water status with $90 \%$ of relative water content. Mineral concentrations in leaves varied from non-mycorrhizal to different type of AMF inocula applied (Table 3). Commercial formulation 1 induced higher levels of $\mathrm{P}$ and magnesium (Mg), Gi plants improved potassium (K) and zinc ( $\mathrm{Zn}$ ) concentration, and lettuce plants inoculated with substrate-based G. mosseae had greater foliar iron (Fe) concentration two months after they had been inoculated.

Under non-saline conditions and three months after seedlings were transplanted and inoculated, shoot biomass of $\mathrm{CI}_{1}$ plants was still higher than the rest of treatments and root dry matter was lower than in NM plants (Table 4). In fact, all mycorrhizal treatments maintained the reduction of its root biomass. At that moment, root colonization achieved 1, 34, 40, and $11 \%$ in $\mathrm{CI}_{1}, \mathrm{CI}_{2}, \mathrm{Gi}$, and $\mathrm{Gm}$ plants respectively. Leaf concentrations of chlorophyll in $\mathrm{CI}_{2}$ and Gi plants and carotenoids in $\mathrm{CI}_{2}, \mathrm{Gi}$, and $\mathrm{Gm}$ plants were enhanced comparing with $\mathrm{NM}$ and $\mathrm{CI}_{1}$ plants. Salinity did not change the growth trend of lettuce plants and did not affect photosynthetic pigments' level, although NM and Gi plants subjected to $100 \mathrm{mM}$ of $\mathrm{NaCl}$ showed a reduction of root biomass comparing with their respective controls under non-saline conditions. The salt stress imposed was not as severe to reduce the relative water content of leaves with the exception of $\mathrm{CI}_{1}$ plants. However, as a result of the high significant interaction between the two factors studied, salinity induced higher mycorrhizal root colonization in lettuce inoculated with substrate-based G. intraradices. 
The effect of salinity in leaf $\mathrm{K}, \mathrm{Mg}$, manganese $(\mathrm{Mn}), \mathrm{Zn}$, iron $(\mathrm{Fe})$, and sodium $(\mathrm{Na})$ concentrations depended on the AMF inocula applied (Table 5). Under non-saline conditions, $\mathrm{K}$ was higher in plants treated with substrate-based inocula, $\mathrm{Mg}$ in $\mathrm{CI}_{1}$ plants, $\mathrm{Mn}$ in $\mathrm{CI}_{1}$ and Gi lettuce, $\mathrm{Zn}$ and $\mathrm{Fe}$ in all mycorrhizal treatments with the exception of $\mathrm{Zn}$ in $\mathrm{CI}_{1}$ plants. Moreover, $\mathrm{CI}_{1}, \mathrm{CI}_{2}$ and $\mathrm{Gi}$ plants showed significantly higher $\mathrm{P}$ concentration in leaves than NM lettuce after 3 months of culture, despite all plants received phosphorus at one-quarter strength.. Salinity caused slight modifications in foliar nutrient concentrations. Only $\mathrm{CI}_{1}$ plants showed higher $\mathrm{P}$ concentration in leaves than $\mathrm{NM}$ lettuce and $\mathrm{K}$ level was not enhanced due to mycorrhizal inoculation. However, salinity increased foliar Fe level in non-mycorrhizal plants, while plants inoculated with bulk inocula reduced it. Salt stress also decreased foliar Ca and Mg concentration in $\mathrm{Gi}$ and $\mathrm{Gm}$ plants, and enhanced leaf $\mathrm{Mn}$ in $\mathrm{Gi}, \mathrm{Gm}$, and $\mathrm{CI}_{2}$ plants. As expected, all plants subjected to $100 \mathrm{mM} \mathrm{NaCl}$ treatment had higher $\mathrm{Na}$ concentration in leaves, with lower values in $\mathrm{CI}_{1}$ plants.

Mineral analysis of commercial formulations was also assessed (Table 6). Commercial inoculum 1 had similar $\mathrm{Ca}, \mathrm{Fe}$, and $\mathrm{Na}$ concentrations as $\mathrm{CI}_{2}$, although it showed significantly higher $\mathrm{N}, \mathrm{P}, \mathrm{K}, \mathrm{Mg}$, and $\mathrm{Zn}$. In contrast, $\mathrm{CI}_{2}$ showed greater Mn level.

Results concerning soluble solutes showed that $\mathrm{CI}_{2}$ plants exhibited the highest leaf starch concentration after three months of culture under non-saline conditions (Figure 1, a1). However, all inoculated plants had lower root starch level than NM lettuce, especially $\mathrm{CI}_{1}$ plants. Total soluble sugar concentration in leaves was similar in non-mycorrhizal and mycorrhizal plants (Figure 1, b1), although Gi plants showed lower root TSS level than NM plants. Under nonsaline conditions, plants inoculated with commercial formulation 1 had the greatest leaf proline 
concentration (Figure 1, c1), while root proline concentration was lower in plants treated with commercial formulations than with bulk inocula. Four weeks treatment with $100 \mathrm{mM} \mathrm{NaCl}$ altered carbohydrate and proline levels of lettuce leaves and roots (Figure 1, a2, b2, c2). Nonmycorrhizal, $\mathrm{CI}_{1}$ and $\mathrm{Gm}$ plants increased foliar starch concentration comparing with their respective controls not subjected to salt stress, while all treatments with the exception of $\mathrm{CI}_{1}$ plants reduced root starch level (Figure 1, a2). Total soluble sugars in leaves showed dissimilar behaviour depending on the mycorrhizal treatment (Figure 1, b2). Plants inoculated with $\mathrm{CI}_{1}$ enhanced foliar TSS concentration due to growing with $100 \mathrm{mM} \mathrm{NaCl}$ and $\mathrm{CI}_{2}$ plants reduced it. In roots, TSS level was maintained as under saline conditions in $\mathrm{CI}_{1}, \mathrm{CI}_{2}$ and $\mathrm{Gi}$ plants, but increased in NM and Gm plants. In reference to proline concentration, plants subjected to salt stress had similar root concentration in comparison with non-saline conditions (Figure 1, c2), although proline leaf concentration of $\mathrm{CI}_{1}$ plants was enhanced.

\section{DISCUSSION}

Plants inoculated with substrate-based $G$. intraradices showed the highest and earliest root mycorrhizal colonization. According to Feldmann (1998), AMF isolates are not genetically homogeneous and thereby their function results in changes of mycorrhizal effectiveness. Formulations $\mathrm{CI}_{1}$ and $\mathrm{CI}_{2}$ contained Glomus intraradices, although only $\mathrm{CI}_{2}$ plants showed good mycorrhizal establishment. Moreover, one of the commercial mycorrhizal product tested, $\mathrm{CI}_{1}$, did not colonize lettuce roots. Studies with commercial formulations have indicated that the qualities of some inocula remain uncertain (Gaur et al., 1998; Tarbell and Koske, 2007). In fact, 
the promises made about the product and the results seen by the end-users are often world's apart, showing that some mycorrhizal products available need greater regulation and control over the production and selling (Alten et al., 2002). According to Tarbell and Koske (2007), the failure of five of the eight commercial inocula to colonize roots of Zea mays when applied at the recommended rate by manufacturers, concerns about the quality and viability of some formulations.

Despite $\mathrm{CI}_{1}$ lettuce plants did not establish symbiosis with $\mathrm{AMF}$, they showed an enhanced shoot growth and leaf nutrient concentration that could be explained by the high levels of $\mathrm{N}, \mathrm{P}, \mathrm{K}, \mathrm{Mg}$, and $\mathrm{Zn}$ quantified after mineral analysis of the commercial product. Excessive $\mathrm{P}$ content of the formulation $\mathrm{CI}_{1}$ could cause the inhibition of mycorrhizal establishment of lettuce roots. Alten et al. (2002) explained that the nutrient content of the mycorrhizal product can be of special importance if high doses of formulation must be used, thus in the processing of the inoculum especially the amount of $\mathrm{P}$ should be reduced.

Mycorrhizal symbiosis can increase shoot and root dry weight of lettuce (Jahromi et al., 2008; Ruiz-Lozano and Azcón, 2000) or maintain as in non-mycorrhizal controls (Kohler et al., 2009). Under non-saline conditions, lettuce plants respond to mycorrhizal inoculation maintaining shoot biomass but reducing the root dry matter without a negative effect in nutrient concentration in leaves. In fact, after three months of culture, $\mathrm{K}, \mathrm{Mg}, \mathrm{Zn}, \mathrm{Fe}$, and $\mathrm{P}$ levels in leaves increased in some inoculated treatments. Moreover, mycorrhizal symbiosis enhanced chlorophyll and carotenoid concentration of lettuce leaves in accordance with previous work of Zuccarini (2007). Higher levels of photosynthetic pigments in mycorrhizal lettuce can be related to a greater nutritional status of plants. However, plants inoculated with $\mathrm{CI}_{1}$ did not show this 
increase in foliar photosynthetic pigment concentration, probably due to a dilution effect caused by its higher shoot biomass. According to Balsam et al. (2011), arbuscular mycorrhizal fungi can enhance nutritional quality and potentially beneficial compounds for human diet (as photosynthetic pigments) in lettuce plants consumed as salads.

Lactuca sativa responses to salt stress have been highly variable according to the cultivar (Shannon et al., 1983). Romaine lettuce is considered a less sensitive lettuce variety (Nasri et al., 2011) although other authors describe as sensitive (Mahmoudi et al., 2010). In our case, four weeks irrigation with $100 \mathrm{mM} \mathrm{NaCl}$, achieving to an electrical conductivity of the substrate of $2.44 \mathrm{mS} \mathrm{cm}{ }^{-1}$, did not affect shoot growth, leaf RWC or foliar photosynthetic pigment concentration in non-mycorrhizal plants, although root biomass was reduced. In addition, the resulting saline condition was enough to reduce root starch concentration with a concomitant increase in leaves. According to Schellenbaum et al. (1998), salinity can induce a preferential partitioning of carbohydrates to the roots, although root starch storage could decrease as a consequence of a decline in photosynthesis due to salinity. On the other hand, salinity enhanced mycorrhizal root colonization by bulk G. intraradices. Kohler et al. (2009) described that the level of colonization in roots of mycorrhizal lettuce plants decreased significantly with increasing $\mathrm{NaCl}$ concentration, while Cantrell and Linderman (2001) did not observe significant differences in AMF root colonization as salt concentration increased. In any case, this fact did not enhanced salt tolerance of Gi plants.

Plants inoculated with formulation 1 and subjected to saline conditions showed a reduction in leaf RWC despite an enhanced foliar proline and TSS concentration. To avoid the osmotic stress caused by salinity, plants may accumulate inorganic ions like $\mathrm{K}^{+}$and low- 
molecular-weight solutes as proline to maintain the internal osmotic potential (Hasegawa et al., 2000), and mycorrhizal symbiosis can improve salt tolerance by improving this osmorregulation (Augé, 2001; Azcón et al., 1996). Despite $\mathrm{CI}_{1}$ plants increased leaf osmolite concentration, this was not high enough to counterbalance the osmotic stress. In contrast, these plants had less leaf $\mathrm{Na}$ concentration than the rest of treatments, probably due to a dilution effect caused by its greater shoot biomass.

Mycorrhization in relation to salt stress did not enhanced $\mathrm{K}$ acquisition but induced higher foliar Mn concentration in Gi and Gm plants. Manganese uptake is competitive with other cations as $\mathrm{Mg}, \mathrm{K}, \mathrm{Ca}$ and $\mathrm{Na}$ (Jones, 2003), and therefore, can be related to some extent to the ability of $\mathrm{Na}$ cation exclusion preventing $\mathrm{Na}$ leaf accumulation and its osmotic injury. On the other hand, the capacity of mycorrhizal fungi to improve some nutrient availability as P,was not maintained under saline conditions, with the exception of $\mathrm{CI}_{1}$ plants. Higher leaf $\mathrm{P}$ concentration observed in $\mathrm{CI}_{1}$ plants may be related to the nutrient content of the formulation applied.

\section{CONCLUSIONS}

One of the commercial formulations of AMF tested did not efficiently colonize lettuce roots. The positive effect on plant growth and nutrition attributed to this formulation was caused by the high mineral content included in the commercial product. In contrast, lettuce inoculated with bulk $G$. intraradices and commercial formulation 2 showed the highest root colonization rates with increased leaf $\mathrm{P}$ and photosynthetic pigment concentrations. A more balanced mineral nutrition together with the maintenance of the photosynthetic capacity (estimated by chlorophyll 
concentration) in mycorrhizal plants could help to counterbalance salt stress. However, four weeks irrigation with $100 \mathrm{mM} \mathrm{NaCl}$ was not severe enough to cause noticeable damage to Romaine lettuce. Mycorrhizal inoculation will be more effective alleviating salt stress with more sensitive lettuce varieties and/or more negative saline conditions.

\section{ACKNOWLEDGMENTS}

This work was supported by Universidad de Alicante (UAUSTI09/04). The authors wish to thank Feli Martínez and Raquel Bravo for technical assistance. 


\section{REFERENCES}

Alten, v.H., Blal, B., Dodd, J.C., Feldmann, F. and M. Vosatka. 2002. Quality control of arbuscular mycorrhizal fungi inoculum in Europe. In Mycorrrhizal Technology in Agriculture. From Genes to Bioproducts, eds. Gianinazzi, S., Schüepp, H., Barea, J.M. and K. Haselwandter, 281-296. Berlin, Germany: Birkhäuser Verlag.

Augé, R.M. 2001. Water relations, drought and vesicular-arbuscular mycorrhizal symbiosis. Mycorrhiza 11: 3-42.

Augé, R.M. and J.W. Stodola. 1990. An apparent increase in symplastic water contributes to greater turgor in mycorrhizal roots of droughted rose plants. New Phytologist 115: 285295.

Azcón, R., Gómez, M. and R. Tobar. 1996. Physiological and nutritional responses by Lactuca sativa L. to nitrogen sources and mycorrhizal fungi under drought conditions. Biology and Fertility of Soils 22: 156-161.

Azcón-Aguilar, C. and J.M. Barea. 1997. Applying mycorrhiza biotechnology to horticulture: significance and potentials. Scientia Horticulturae 68: 1-24.

Barassi, C.A., Ayrault, G., Creus, C.M., Sueldo, R.J. and M.T. Sobrero. 2006. Seed inoculation with Azospirillum mitigates $\mathrm{NaCl}$ effects on lettuce. Scientia Horticulturae 109: 8-14.

Baslam, M., Garmendia, I. and N., Goicoechea. 2011. Arbuscular mycorrhizal fungi (AMF) improved growth and nutritional quality of greenhouse-grown lettuce. Journal of Agricultural and Food Chemistry 59: 5504-5515. 
Cantrell, I.C. and R.G. Linderman. 2001. Preinoculation of lettuce and onion with VA mycorrhizal fungi reduces deleterious effects of soil salinity. Plant and Soil 233: 269281.

Duque, F. 1971. Joint determination of phosphorus, potassium, calcium, iron, manganese, copper and zinc in plants. Anales de Edafología y Agrobiología 30: 207-229. [In Spanish]

Feldmann, F. 1998. The strain-inherent variability of arbuscular mycorrhizal effectiveness: II. Effectiveness of single spores. Symbiosis 25: 131-143.

Gaur, A., Adholeya, A. and K.G. Mukerji. 1998. A comparison of AM fungi inoculants using Capsicum and Polianthes in marginal soil amended with organic matter. Mycorrhiza 7: 307-312.

Hasegawa, P.M., Bressan, R.A., Zhu, K.L. and H.J. Bohnert. 2000. Plant cellular and molecular responses to high salinity. Annual Review in Plant Physiology and Plant Molecular Biology 51: 463-499.

Hayman, D.S., Barea, J.M. and R. Azcón. 1976. Vesicular-arbuscular mycorrhiza in southern Spain: its distribution in crops growing in soil of different fertility. Phytopathology of the Mediterranean 15: 1-6.

Hewitt, E.J. 1966. Sand and water culture methods used in the study of plant nutrition. In Commonwealth Agricultural Bureaux. London, Technical communication No. 22, 2d edn. rev.

Irigoyen, J.J., Emerich, D.W. and M. Sánchez-Díaz. 1992. Water stress induced changes in concentrations of proline and total soluble sugars in nodulated alfalfa (Medicago sativa) plants. Physiologia Plantarum 84: 55-60. 
Jahromi, F., Aroca, R., Porcel, R. and J.M. Ruiz-Lozano. 2008. Influence of salinity on the in vitro development of Glomus intraradices and on the in vivo physiological and molecular responses of mycorrhizal lettuce plants. Microbial Ecology 55: 45-53.

Jarvis, C.E. and J.R.L.Walker. 1993. Simultaneous, rapid, spectrophotometric determination of total starch, amylose and amylopectin. Journal of the Science of Food and Agriculture 63: 53-57.

Jeffries, P., Gianinazzi, S., Perotto, S., Turnau, K. and J.M Barea. 2003. The contribution of arbuscular mycorrhizal fungi in sustainable maintenance of plant health and soil fertility. Biology and Fertility of Soils 37: 1-46.

Jones, J.B. 2003. Plant Mineral Nutrition. In: Agronomic Handbook: Management of Crops, Soils and Their Fertility, ed. J.J. Jones, 291-334. USA: CRC Press.

Kim, H.J., Fonseca, J.M., Choi, J.H., Kubota, C. and D.Y. Kwon. 2008. Salt in irrigation water affects the nutritional and visual properties of romaine lettuce (Lactuca sativa L.). Journal of Agricultural and Food Chemistry 56: 3772-3776.

Kohler, J., Hernández, J.A., Caravaca, F. and A. Roldán. 2009. Induction of antioxidant enzymes is involved in the greater effectiveness of a PGPR versus AM fungi with respect to increasing the tolerance of lettuce to severe salt stress. Environmental and Experimental Botany 65: 245-252.

Lichtenthaler, H.K. 1987. Chlorophylls and carotenoids: pigments of photosynthetic biomembranes. Methods in Enzymology 148: 350-382.

Mahmoudi, H., Huang, J., Gruber, M.Y., Kaddour, R., Lachaâl, M., Ouerghi, Z. and A. Hannoufa. 2010. The impact of genotype and salinity o physiological function, secondary 
metabolite accumulation, and antioxidative responses in lettuce. Journal of Agricultural and Food Chemistry 58: 5122-5130.

Martínez , V., Bernstein, N. and A. Läuchli. 1996. Salt-induced inhibition of phosphorus transport in lettuce plants. Physiologia Plantarum 97: 118-122.

Nasri, N., Kaddour, R., Rabhi, M., Plassard, C. and M. Lachaal. 2011. Effect of salinity on germination, phytase activity and phytate content in lettuce seddling. Acta Physiologiae Plantarum 33: 935-942.

Ojala, J.C., Jarrell, W.M., Menge, J.A. and E.L.V. Johnson. 1983. Influence of mycorrhizal fungi on the mineral nutrition and yield of onion in saline soil. Agronomy Journal 75: 255-259.

Phillips, J.M. and D.S. Hayman. 1970. Improved procedures for clearing roots and staining parasitic and vesicular-arbuscular mycorrhizal fungi for rapid assessment of infection. Transactions of the British Mycological Society 55: 158-161.

Ruiz-Lozano, J.M. and R. Azcón. 1995. Hyphal contribution to water uptake in mycorrhizal plants as affected by the fungal species and water status. Physiologia Plantarum 95: 472478.

Ruiz-Lozano, J.M. and R. Azcón. 2000. Symbiotic efficiency and infectivity of an autochthonous arbuscular mycorrhizal Glomus sp. from saline soils and Glomus deserticola under salinity. Mycorrhiza 10: 137-143.

Shannon, M. C., McCreight, C. and J.H. Draper. 1983. Screening tests for salt tolerance in lettuce. Journal of the American Society for Horticultural Science 108: 225-230.

Schellenbaum, L., Müller, J., Boller, T., Wienken, A. and H. Schüepp. 1998. Effects of drought on non-mycorrhizal and mycorrhizal maize: changes in the pools of non-structural 
carbohydrates, in the activities of invertase and trehalose, and in the pools of amino acids and imino acids. New Phytologist 138: 59-66.

Schenck, N.C. 1982. Methods and Principles of Mycorrhizal Research, St. Paul, Minnesota, U.S.A.: The American Phytopathological Society.

Séstak, Z., Càtsky , J. and P. Jarvis. 1971. Plant Photosynthetic Production. Manual of Methods. The Hague, The Netherlands: Dr Junk Publishers.

Tarbell, T.J. and R.E. Koske. 2007. Evaluation of commercial arbuscular mycorrhizal inocula in a sand/peat medium. Mycorrhiza 18: 51-56.

Weatherley, P.E. 1950. Studies in the water relations of the cotton plant. I. The field measurements of water deficit in leaves. New Phytologist 49: 81-87.

Yemm, E.W. and A.J. Willis. 1954. The estimation of carbohydrates in plant extracts by anthrone. Biochemical Journal 57: 508-514.

Zuccarini, P. 2007. Mycorrhizal infection ameliorates chlorophyll content and nutrient uptake of lettuce exposed to saline irrigation. Plant, Soil and Environment 53: 283-289. 
Figure 1. Starch (a1, a2), total soluble sugars (b1, b2) and proline (c1, c2) concentrations in nonmycorrhizal (NM) and mycorrhizal lettuce plants inoculated with commercial inocula $1\left(\mathrm{CI}_{1}\right)$ or $2\left(\mathrm{CI}_{2}\right)$, and substrate-based Glomus intraradices $(\mathrm{Gi})$ or Glomus mosseae $(\mathrm{Gm})$ three months after transplanting and subjected to different salt concentrations. Means \pm SD ( $\mathrm{n}=7-9$ plants) were compared with the Tukey-b test. Within each parameter histograms with the same letter do not differ significantly $(P<0.05)$.

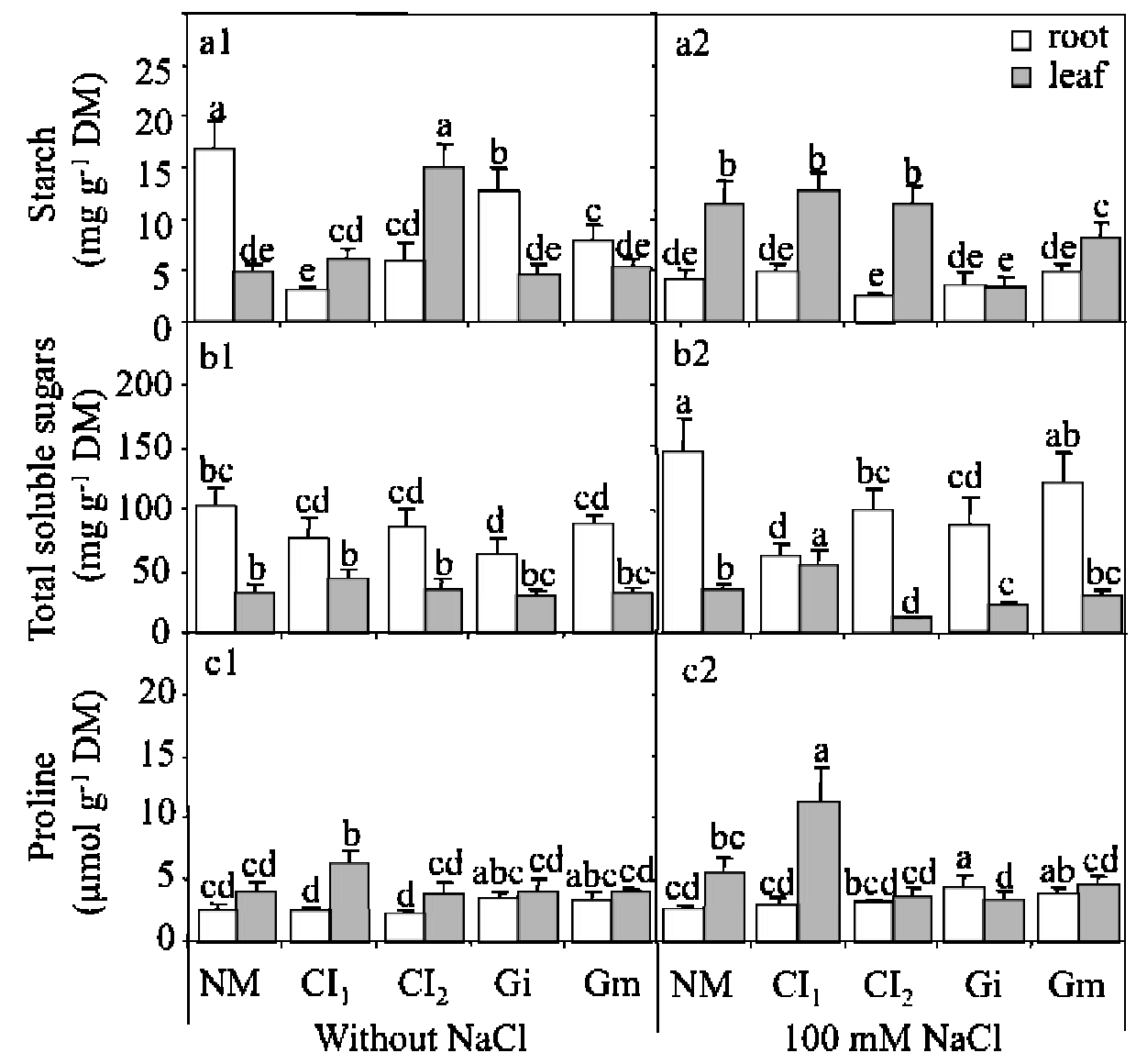

Saline condition 
Table 1 Number of propagules in formulations of AMF and rates of inoculum applied.

\begin{tabular}{lcccc}
\hline Treatment & $\begin{array}{c}\text { Number of } \\
\text { propagules per }\end{array}$ & Number of & Recommended & Formulation \\
& litre of & litre according to & manufacturers & pot $(\mathrm{mL})$ \\
& formulation* & manufacturers & (mL per pot) & \\
& - & 75,000 & $4-8$ & 25 \\
\hline Commercial 1 $\left(\mathrm{CI}_{1}\right)$ & - & 200,000 & 5 & 25 \\
Commercial 2 $\left(\mathrm{CI}_{2}\right)$ & 2,280 & - & - & 100 \\
G. intraradices $(\mathrm{Gi})$ & 2,230 & - & - & 100 \\
G. mosseae $(\mathrm{Gm})$ & & & & \\
\end{tabular}

*based on data from a Most Probable Number (MPN) bioassay. 
Table 2 Shoot and root dry matter (DM), mycorrhizal colonization, leaf relative water content (RWC) and photosynthetic pigment concentration in non-mycorrhizal (NM) and mycorrhizal lettuce plants inoculated with commercial inoculum $1\left(\mathrm{CI}_{1}\right)$ or $2\left(\mathrm{CI}_{2}\right)$ and substrate-based Glomus intraradices (Gi) or Glomus mosseae (Gm) two months after transplanting and before the salt stress was imposed.

\begin{tabular}{lcccccc}
\hline Treatment & $\begin{array}{c}\text { Shoot DM } \\
\left(\text { g plant }^{-1}\right)\end{array}$ & $\begin{array}{c}\text { Root DM } \\
\left(\text { g plant }^{-1}\right)\end{array}$ & $\begin{array}{c}\text { Mycorrhizal } \\
\text { colonization }(\%)\end{array}$ & $\begin{array}{c}\text { RWC } \\
(\%)\end{array}$ & $\begin{array}{c}\text { Chl a+b } \\
\left(\mathrm{mg} \mathrm{g}^{-1} \mathrm{DM}\right)\end{array}$ & $\begin{array}{c}\text { Carotenoids } \\
\left(\mathrm{mg} \mathrm{g}^{-1} \mathrm{DM}\right)\end{array}$ \\
\hline $\mathrm{NM}$ & $2.8 \mathrm{~b}$ & $1.4 \mathrm{a}$ & - & $91.5 \mathrm{a}$ & $11.8 \mathrm{c}$ & $1.8 \mathrm{~b}$ \\
$\mathrm{CI}_{1}$ & $8.3 \mathrm{a}$ & $1.1 \mathrm{~b}$ & $0.5 \mathrm{~b}$ & $84.2 \mathrm{a}$ & $14.4 \mathrm{bc}$ & $2.4 \mathrm{ab}$ \\
$\mathrm{CI}_{2}$ & $1.3 \mathrm{~b}$ & $0.6 \mathrm{c}$ & $0.9 \mathrm{~b}$ & $94.9 \mathrm{a}$ & $16.9 \mathrm{ab}$ & $2.9 \mathrm{ab}$ \\
$\mathrm{Gi}$ & $1.6 \mathrm{~b}$ & $0.5 \mathrm{c}$ & $42.0 \mathrm{a}$ & $92.0 \mathrm{a}$ & $19.4 \mathrm{a}$ & $3.4 \mathrm{a}$ \\
$\mathrm{Gm}$ & $1.7 \mathrm{~b}$ & $0.5 \mathrm{c}$ & $1.3 \mathrm{~b}$ & $94.4 \mathrm{a}$ & $20.4 \mathrm{a}$ & $3.5 \mathrm{a}$
\end{tabular}

Means ( $\mathrm{n}=4$ plants) were analysed with one-way ANOVA, and least significant differences were evaluated by the Tukey-b test. Within each column values followed by a common letter are not significantly different $(P<0.05)$. 
Table 3 Foliar concentration of nutrients in non-mycorrhizal (NM) and mycorrhizal lettuce plants inoculated with commercial inoculum $1\left(\mathrm{CI}_{1}\right)$ or $2\left(\mathrm{CI}_{2}\right)$ and substrate-based Glomus intraradices $(\mathrm{Gi})$ or Glomus mosseae (Gm) two months after transplanting and before the salt stress was imposed. Otherwise as for Table 2.

\begin{tabular}{lccccccccc}
\hline Treatment & $\begin{array}{c}\mathrm{N} \\
\left(\mathrm{g} \mathrm{kg}^{-1}\right)\end{array}$ & $\begin{array}{c}\mathrm{P} \\
\left(\mathrm{g} \mathrm{kg}^{-1}\right)\end{array}$ & $\begin{array}{c}\mathrm{K} \\
\left(\mathrm{g} \mathrm{kg}^{-1}\right)\end{array}$ & $\begin{array}{c}\mathrm{Ca} \\
\left(\mathrm{g} \mathrm{kg}^{-1}\right)\end{array}$ & $\begin{array}{c}\mathrm{Mg} \\
\left(\mathrm{g} \mathrm{kg}^{-1}\right)\end{array}$ & $\begin{array}{c}\mathrm{Mn} \\
\left(\mathrm{mg} \mathrm{kg}^{-1}\right)\end{array}$ & $\begin{array}{c}\mathrm{Zn} \\
\left(\mathrm{mg} \mathrm{kg}^{-1}\right)\end{array}$ & $\begin{array}{c}\mathrm{Fe} \\
\left(\mathrm{mg} \mathrm{kg}^{-1}\right)\end{array}$ & $\begin{array}{c}\mathrm{Na} \\
\left(\mathrm{mg} \mathrm{kg}^{-}\right.\end{array}$ \\
\hline $\mathrm{NM}$ & $22.6 \mathrm{a}$ & $1.0 \mathrm{~b}$ & $36.9 \mathrm{~b}$ & $7.8 \mathrm{a}$ & $3.1 \mathrm{~b}$ & $70.11 \mathrm{ab}$ & $49.39 \mathrm{~b}$ & $87.63 \mathrm{~b}$ & $7544 \mathrm{a}$ \\
$\mathrm{CI}_{1}$ & $26.0 \mathrm{a}$ & $3.3 \mathrm{a}$ & $47.8 \mathrm{ab}$ & $9.0 \mathrm{a}$ & $4.4 \mathrm{a}$ & $108.68 \mathrm{a}$ & $45.83 \mathrm{~b}$ & $101.02 \mathrm{~b}$ & $5445 \mathrm{a}$ \\
$\mathrm{CI}_{2}$ & $24.0 \mathrm{a}$ & $1.2 \mathrm{~b}$ & $44.0 \mathrm{ab}$ & $8.4 \mathrm{a}$ & $2.9 \mathrm{~b}$ & $48.97 \mathrm{~b}$ & $52.92 \mathrm{~b}$ & $84.25 \mathrm{~b}$ & $5909 \mathrm{a}$ \\
$\mathrm{Gi}$ & $28.7 \mathrm{a}$ & $1.4 \mathrm{~b}$ & $56.2 \mathrm{a}$ & $9.4 \mathrm{a}$ & $3.8 \mathrm{ab}$ & $80.74 \mathrm{ab}$ & $92.32 \mathrm{a}$ & $123.79 \mathrm{ab}$ & $6756 \mathrm{a}$ \\
$\mathrm{Gm}$ & $25.8 \mathrm{a}$ & $1.3 \mathrm{~b}$ & $45.1 \mathrm{ab}$ & $8.1 \mathrm{a}$ & $3.2 \mathrm{~b}$ & $68.15 \mathrm{ab}$ & $49.23 \mathrm{~b}$ & $156.97 \mathrm{a}$ & $5865 \mathrm{a}$
\end{tabular}


Table 4 Shoot and root dry matter (DM), mycorrhizal colonization, leaf relative water content (RWC) and photosynthetic pigment concentration in non-mycorrhizal $(\mathrm{NM})$ and mycorrhizal lettuce plants inoculated with commercial inoculum $1\left(\mathrm{CI}_{1}\right)$ or $2\left(\mathrm{CI}_{2}\right)$ and substrate-based Glomus intraradices $(\mathrm{Gi})$ or Glomus mosseae $(\mathrm{Gm})$ three months after transplanting and subjected to different salt conditions.

\begin{tabular}{lcccccc}
\hline Treatment & Shoot DM & Root DM & Mycorrhizal & RWC & Chl a+b & Carotenoids \\
& $\left(\mathrm{g} \mathrm{plant}^{-1}\right)$ & $\left(\mathrm{g} \mathrm{plant}^{-1}\right)$ & colonization $(\%)$ & $(\%)$ & $\left(\mathrm{mg} \mathrm{g}^{-1} \mathrm{DM}\right)$ & $\left(\mathrm{mg} \mathrm{g}^{-1} \mathrm{DM}^{2}\right.$ \\
\hline Without $\mathrm{NaCl}$ & & & & & & \\
$\mathrm{NM}$ & $3.1 \mathrm{~b}$ & $1.7 \mathrm{a}$ & - & $89.8 \mathrm{ab}$ & $13.6 \mathrm{bc}$ & $2.2 \mathrm{c}$ \\
$\mathrm{CI}_{1}$ & $8.5 \mathrm{a}$ & $1.2 \mathrm{bc}$ & $0.6 \mathrm{~d}$ & $84.4 \mathrm{ab}$ & $15.0 \mathrm{bc}$ & $2.1 \mathrm{c}$ \\
$\mathrm{CI}_{2}$ & $2.0 \mathrm{~b}$ & $0.8 \mathrm{~d}$ & $33.9 \mathrm{~b}$ & $92.8 \mathrm{a}$ & $18.2 \mathrm{a}$ & $3.0 \mathrm{a}$ \\
$\mathrm{Gi}$ & $2.9 \mathrm{~b}$ & $1.3 \mathrm{~b}$ & $39.6 \mathrm{~b}$ & $82.8 \mathrm{ab}$ & $18.7 \mathrm{a}$ & $2.9 \mathrm{a}$ \\
$\mathrm{Gm}$ & $2.6 \mathrm{~b}$ & $1.1 \mathrm{bcd}$ & $11.4 \mathrm{c}$ & $83.8 \mathrm{ab}$ & $16.7 \mathrm{ab}$ & $2.7 \mathrm{ab}$ \\
$100 \mathrm{mM} \mathrm{NaCl}$ & & & & & & \\
$\mathrm{NM}$ & $2.7 \mathrm{~b}$ & $1.3 \mathrm{~b}$ & - & $90.7 \mathrm{a}$ & $12.4 \mathrm{c}$ & $2.1 \mathrm{c}$
\end{tabular}




\begin{tabular}{lcccccc}
$\mathrm{CI}_{1}$ & $8.9 \mathrm{a}$ & $1.3 \mathrm{~b}$ & $0.4 \mathrm{~d}$ & $79.3 \mathrm{~b}$ & $16.8 \mathrm{ab}$ & $2.4 \mathrm{bc}$ \\
$\mathrm{CI}_{2}$ & $2.2 \mathrm{~b}$ & $0.7 \mathrm{~d}$ & $38.2 \mathrm{~b}$ & $89.8 \mathrm{ab}$ & $16.5 \mathrm{ab}$ & $2.7 \mathrm{ab}$ \\
$\mathrm{Gi}$ & $3.0 \mathrm{~b}$ & $0.9 \mathrm{~cd}$ & $58.8 \mathrm{a}$ & $85.2 \mathrm{ab}$ & $16.1 \mathrm{ab}$ & $2.6 \mathrm{ab}$ \\
$\mathrm{Gm}$ & $2.5 \mathrm{~b}$ & $0.8 \mathrm{~d}$ & $8.1 \mathrm{c}$ & $86.2 \mathrm{ab}$ & $17.4 \mathrm{ab}$ & $2.9 \mathrm{a}$ \\
\hline Saline stress & $*$ & $* *$ & $* * *$ & $\mathrm{~ns}$ & $\mathrm{~ns}$ & $\mathrm{~ns}$ \\
$\mathrm{AMF}$ & $* * *$ & $* * *$ & $* * *$ & $* * *$ & $* * *$ & $* * *$ \\
Interaction & $*$ & $\mathrm{~ns}$ & $* * *$ & $\mathrm{~ns}$ & $*$ & $\mathrm{~ns}$ \\
\hline
\end{tabular}

Data were analysed with two-way ANOVA with AMF and salt stress as the main effects. Means (n=7-9 plants) were calculated and, when the $\mathrm{F}$ ratio was significant, least significant differences were evaluated by the Tukey-b test. ns, *, **, and *** indicated respectively non-significant or significant at 5\%,1\% and $0,1 \%$ levels. Within each column values followed by a common letter are not significantly different $(\mathrm{P}<0.05)$. 
Table 5. Foliar concentration of nutrients in leaves in non-mycorrhizal (NM) and mycorrhizal lettuce plants inoculated with commercial inoculum $1\left(\mathrm{CI}_{1}\right)$ or $2\left(\mathrm{CI}_{2}\right)$ and substrate-based Glomus intraradices $(\mathrm{Gi})$ or Glomus mosseae $(\mathrm{Gm})$ three months after transplanting and subjected to different salt conditions. Otherwise as for Table 4.

\begin{tabular}{|c|c|c|c|c|c|c|c|c|c|}
\hline Treatment & $\begin{array}{c}\mathrm{N} \\
\left(\mathrm{g} \mathrm{kg}^{-1}\right)\end{array}$ & $\begin{array}{c}\mathrm{P} \\
\left(\mathrm{g} \mathrm{kg}^{-1}\right)\end{array}$ & $\begin{array}{c}\mathrm{K} \\
\left(\mathrm{g} \mathrm{kg}^{-1}\right)\end{array}$ & $\begin{array}{c}\mathrm{Ca} \\
\left(\mathrm{g} \mathrm{kg}^{-1}\right)\end{array}$ & $\begin{array}{c}\mathrm{Mg} \\
\left(\mathrm{g} \mathrm{kg}^{-1}\right)\end{array}$ & $\begin{array}{c}\mathrm{Mn} \\
\left(\mathrm{mg} \mathrm{kg}^{-1}\right)\end{array}$ & $\begin{array}{c}\mathrm{Zn} \\
\left(\mathrm{mg} \mathrm{kg}^{-1}\right)\end{array}$ & $\begin{array}{c}\mathrm{Fe} \\
\left(\mathrm{mg} \mathrm{kg}^{-1}\right)\end{array}$ & $\begin{array}{c}\mathrm{Na} \\
\left(\mathrm{mg} \mathrm{kg}^{-1}\right)\end{array}$ \\
\hline \multicolumn{10}{|c|}{ Without $\mathrm{NaCl}$} \\
\hline NM & $29.6 \mathrm{abc}$ & $1.6 \mathrm{c}$ & $56.8 \mathrm{bcd}$ & $16.3 \mathrm{a}$ & $5.7 \mathrm{~b}$ & $89.1 \mathrm{~d}$ & $64.1 \mathrm{ef}$ & $85.8 \mathrm{c}$ & $8430 \mathrm{c}$ \\
\hline $\mathrm{CI}_{1}$ & $28.0 \mathrm{bc}$ & $3.8 \mathrm{a}$ & $52.4 \mathrm{~cd}$ & $15.3 \mathrm{ab}$ & $6.8 \mathrm{a}$ & $133.9 \mathrm{bc}$ & $52.8 \mathrm{f}$ & $103.4 \mathrm{ab}$ & $3519 \mathrm{c}$ \\
\hline $\mathrm{CI}_{2}$ & $33.3 \mathrm{a}$ & $2.4 \mathrm{~b}$ & $60.0 \mathrm{abc}$ & $14.8 \mathrm{ab}$ & $5.2 \mathrm{bc}$ & $84.2 \mathrm{~d}$ & $105.3 \mathrm{c}$ & $113.7 \mathrm{ab}$ & $4878 \mathrm{c}$ \\
\hline Gi & $33.4 \mathrm{a}$ & $2.5 \mathrm{~b}$ & $68.9 \mathrm{a}$ & $15.1 \mathrm{ab}$ & $5.8 \mathrm{ab}$ & $131.7 \mathrm{bc}$ & $157.8 \mathrm{a}$ & $114.0 \mathrm{ab}$ & $6478 c$ \\
\hline $\mathrm{Gm}$ & $31.1 \mathrm{ab}$ & $2.1 \mathrm{bc}$ & $68.3 \mathrm{a}$ & $15.1 \mathrm{ab}$ & $5.8 \mathrm{ab}$ & $118.5 \mathrm{~cd}$ & $97.8 \mathrm{c}$ & $111.4 \mathrm{ab}$ & $5954 \mathrm{c}$ \\
\hline \multicolumn{10}{|c|}{$100 \mathrm{mM} \mathrm{NaCl}$} \\
\hline $\mathrm{NM}$ & $27.7 \mathrm{bc}$ & $2.2 \mathrm{bc}$ & $57.2 \mathrm{bcd}$ & $14.1 \mathrm{ab}$ & $5.4 \mathrm{~b}$ & $119.9 \mathrm{~cd}$ & $84.5 \mathrm{de}$ & $120.2 \mathrm{a}$ & $24936 \mathrm{a}$ \\
\hline $\mathrm{CI}_{1}$ & $27.1 \mathrm{c}$ & $3.9 \mathrm{a}$ & $62.7 \mathrm{ab}$ & $15.6 \mathrm{ab}$ & $6.8 \mathrm{a}$ & $161.8 \mathrm{~b}$ & $64.5 \mathrm{ef}$ & $117.9 \mathrm{ab}$ & $17506 \mathrm{~b}$ \\
\hline $\mathrm{CI}_{2}$ & $30.1 \mathrm{abc}$ & $2.4 \mathrm{~b}$ & $58.5 \mathrm{bcd}$ & $12.4 \mathrm{bc}$ & $4.4 \mathrm{c}$ & $139.5 \mathrm{bc}$ & $137.0 \mathrm{~b}$ & $88.5 \mathrm{bc}$ & $26059 \mathrm{a}$ \\
\hline Gi & $29.0 \mathrm{abc}$ & $2.2 \mathrm{bc}$ & $64.5 \mathrm{ab}$ & $11.4 \mathrm{c}$ & $4.3 \mathrm{c}$ & $212.5 \mathrm{a}$ & $172.4 \mathrm{a}$ & $86.1 \mathrm{c}$ & $25357 \mathrm{a}$ \\
\hline
\end{tabular}




\begin{tabular}{lccccccccc}
$\mathrm{Gm}$ & $26.9 \mathrm{c}$ & $2.0 \mathrm{bc}$ & $50.1 \mathrm{~d}$ & $12.0 \mathrm{bc}$ & $4.4 \mathrm{c}$ & $170.3 \mathrm{~b}$ & $84.6 \mathrm{de}$ & $88.2 \mathrm{bc}$ & $29896 \mathrm{a}$ \\
\hline Saline stress & $* * *$ & $\mathrm{~ns}$ & $\mathrm{~ns}$ & $* * *$ & $* * *$ & $* * *$ & $* * *$ & $\mathrm{~ns}$ & $* * *$ \\
$\mathrm{AMF}$ & $* * *$ & $* * *$ & $* * *$ & $*$ & $* * *$ & $* * *$ & $* * *$ & $\mathrm{~ns}$ & $* *$ \\
Interaction & $\mathrm{ns}$ & $\mathrm{ns}$ & $* * *$ & $\mathrm{~ns}$ & $* *$ & $*$ & $* *$ & $* * *$ & $*$ \\
\hline
\end{tabular}

Table 6. Concentration of nutrients in commercial formulations $1\left(\mathrm{CI}_{1}\right)$ and $2\left(\mathrm{CI}_{2}\right)$ of $\mathrm{AMF}$.

\begin{tabular}{lccccccccc}
\hline Formulation & $\mathrm{N}$ & $\mathrm{P}$ & $\mathrm{K}$ & $\mathrm{Ca}$ & $\mathrm{Mg}$ & $\mathrm{Mn}$ & $\mathrm{Zn}$ & $\mathrm{Fe}$ & $\mathrm{Na}$ \\
& $\left(\mathrm{g} \mathrm{kg}^{-1}\right)$ & $\left(\mathrm{g} \mathrm{kg}^{-1}\right)$ & $\left(\mathrm{g} \mathrm{kg}^{-1}\right)$ & $\left(\mathrm{g} \mathrm{kg}^{-1}\right)$ & $\left(\mathrm{g} \mathrm{kg}^{-1}\right)$ & $\left(\mathrm{mg} \mathrm{kg}^{-1}\right)$ & $\left(\mathrm{mg} \mathrm{kg}^{-1}\right)$ & $\left(\mathrm{mg} \mathrm{kg}^{-1}\right)$ & $\left(\mathrm{mg} \mathrm{kg}^{-1}\right)$ \\
\hline $\mathrm{CI}_{1}$ & $12.0 \mathrm{a}$ & $8.9 \mathrm{a}$ & $15.2 \mathrm{a}$ & $18.2 \mathrm{a}$ & $18.0 \mathrm{a}$ & $307.5 \mathrm{~b}$ & $190.2 \mathrm{a}$ & $20302 \mathrm{a}$ & $1402 \mathrm{a}$ \\
$\mathrm{CI}_{2}$ & $1.8 \mathrm{~b}$ & $0.2 \mathrm{~b}$ & $1.5 \mathrm{~b}$ & $16.8 \mathrm{a}$ & $2.6 \mathrm{~b}$ & $1196.0 \mathrm{a}$ & $44.8 \mathrm{~b}$ & $17130 \mathrm{a}$ & $1219 \mathrm{a}$ \\
\hline
\end{tabular}

Means $(n=4)$ were compared with the Student's $t$-test within each column. Values followed by a common letter are nor significantly different $(P<0.05)$. 
